\title{
Poetry: For Harvey Milk and Comstock Correctional Upstate New York
}

\author{
Becky Thompson
}

\section{For Harvey Milk}

When you reached your arms out to Dan White did you know he had a gun? Did his locked jaw warn

you? Is this why you had a camera shop, to photograph the present? Did you know we lit

a galaxy of candles on Castro Street and that the boy in Iowa saw you on TV? When James Byrd was dragged

through the streets, did you feel his spirit?

\section{Comstock Correctional Upstate New York for David Gilbert*}

on my first visit ice packs my tire treads my car spins around to head home in the snow parking lot divides: visitors and corrections I drive around in circles, car pacing

the guards see my first time eyes search my bag and body, smiling my underwire bra the threat they enjoy fondling, passing it from one guard to the next

a series of doors slam shut each metal clink I feel smaller bathroom walls smell of steel gurneys vending machines spit out Hormel's chili 
the numbers assigned press us together rows of women with lipstick holding infants with ribbons I stare at the door where the prisoners emerge privacy between visitors an invisible line

you enter the room, stride gentle, palms open, your hard-earned blue tee under prison shirt grey yellow formica table stockades our legs your hands, Jewish dancing, eyes as big as the clock

I start in with questions, you talk fast, I scribble, no tape recorder allowed, I chronicle long hand my questions review the drama of Black Power armed struggle, you explain, another word for defense

my pacifist leanings collide with your logic: they shot Hampton in his bed, assassinated Malcolm I couldn't keep running for white cover in college underground life teetered our judgments

my body stays tense with secretary's function each inmate who enters you hold with your eyes tender man in this dungeon, life sentence, I am sinking you see me falling, ask: are you breathing?

you reach across distance, a light brush on my arm your touch sends electricity I had reserved just for women my twenty years lesbian falling into your body, interview shifts from subject to belonging

I leave before count, thirty-five pages in hand officers' cajoling, a cover for terror they unlock and lock the maze to the outside, a part of me stays, slipped inside your skin.

${ }^{*}$ David Gilbert, a member of the Weather Underground in the late 1960s and 1970s, was sentenced to life in prison for his involvement in the 1981 Brinks robbery. He continues to do antiracist work in prison.

Becky Thompson

2007 